\title{
Yoğun Bakım Ünitesinde Takip Edilen Kafa Travmalı Hastaların Geriye Dönük Olarak Değerlendirilmesi ve Risk Skorlarının Prognoza Etkisi
}

\section{Retrospective Evaluation of Patients with Head Trauma Followed Upin the Inten- sive Care Unit and Effect of Risk Scores on Prognosis}

\author{
Tuğba BINGÖL TANRIVERDi ${ }^{1}(\mathbb{D})$, Taner ENGIN ${ }^{2}$

\begin{abstract}
${ }^{1}$ Sağlık Bilimleri Üniversitesi, Mehmet Akif İnan Eğitim ve Araştırma Hastanesi, Anesteziyoloji ve Reanimasyon Bölümü, Şanlıurfa, Türkiye
\end{abstract} \\ ${ }^{2}$ Sağlık Bilimleri Üniversitesi, Mehmet Akif İnan Eğitim ve Araştırma Hastanesi, Beyin ve Sinir Cerrahisi Bölümü, Şanlıurfa, Türkiye
}

öz.

Amaç: Kafa travması sık görülen ve yoğun bakım takibi gerektirebilen önemli bir halk sağlığı problemidir. İlerleyen teknolojiler ve yoğun tedavilere rağmen kafa travması geçiren hastaların prognozu kötüdür ve çoğunda sekel ve/veya ölüm gözlenmektedir. Bu nedenle, kafa travmalarında kötü prognoza sahip olan yüksek riskli hastaları belirleyebilmek önemlidir. Glaskow koma skalası (GKS), yaralanma şiddet skoru (injury severity score, ISS) ve revize travma skoru (RTS) kafa travmalı hastaların ilk değerlendirmesinde olumsuz sonuçları tahmin etmede ve klinik karar vermede en çok kullanılan puanlama sistemleridir. Çalışmamızın amacı kafa travması nedeniyle hastanemiz yoğun bakımında takip edilen hastaların klinik özelliklerini sunmak ve kullanılan klinik risk skorlarının hastane içi sonlanımlara etkisini saptamaktır.

Materyal ve metot: Ocak 2019 - Mayıs 2021 tarihleri arasında hastanemiz yoğun bakımında kafa travması nedeniyle takip edilen 104 hasta geriye dönük olarak tarandı ve çalışmamıza dahil edildi. Hastaların dosyaları, arşiv kayıtları ve hastane otomasyon kayıt sistemi ayrıntılı olarak incelendi. Tüm hastaların GKS, ISS ve RTS değerleri belirlenerek prognoza etkileri incelendi. Bulgular: Hastaların yas ortancası 24.5 (12.0-39.8) yıl ve 85'i $(\% 81,7)$ erkek cinsiyette idi. Başvurudaki GKS ortancası 13 (9.315.0), ISS ortancası 25 (25-41), RTS ortancası ise 11 (9-12) olarak tespit edildi. 19-64 yaş aralığı dışındaki diğer tüm yaş kategorilerinde kafa travmasının en sık nedeni yüksekten düşme idi. Ancak, bu yaş aralığında en sık neden patlama veya ateşli silah yaralanması (\%31.4) idi. Hastane içi ölüm 16 (\%15.4) hastada meydana geldi. Hastane içi ölüm gelişmeyen hastalar ile karşılaştırıldı̆ıında; ölüm gelişen hastaların başvuru sırasındaki ISS değerleri anlamlı olarak daha yüksek iken ( $P<0.001)$, RTS $(P<0.001)$ ve GKS $(P<0.001)$ değerleri anlamlı olarak daha düşük idi. RTS'nin hastane içi ölümü öngördürmedeki AUC değeri (0.968), ISS (0.947) ve GKS'nin (0.866) AUC değerlerinden daha yüksek olarak tespit edildi.

Sonuç: Çalışmamızda, yoğun bakımda yatan kafa travmalı hastalarda günlük pratikte en çok kullanılan risk skorlarının hastane içi ölümü öngörmedeki rolleri araştırıldı. Her ne kadar başvurudaki risk skorları hastane içi prognozu kötü olabilecek yüksek riskli hastaları öngörmede iyi bir tanısal değere sahip olsa da,RTS'nin diğer klinik risk skorlarına göre ölümü öngörmede daha üstün bir skor olduğu tespit edildi.

Anahtar kelimeler: Kafa travması, hastane içi ölüm, klinik risk skorları

Abstract

Background: Head trauma is an important public health problem that is common seen and may require intensive care followup. Despite advanced technologies and intensive treatments, patients with head trauma have poor prognosis and sequelae and/or death have been observed most of these patients. Therefore, it is important to identify high-risk patients with poor prognosis in head trauma. Glasgow coma scale (GCS), injury severity score (ISS) and revised trauma score (RTS) are the most widely used scoring systems for predicting adverse outcomes and clinical decision making in the initial evaluation of patients with head trauma. The aim of our study is to present the clinical characteristics of patients followed in the intensive care unit of our hospital due to head trauma and to determine the effect of used clinical risk scores on in-hospital outcomes.

Materials and Methods: A total of 104 patients who were followed up in intensive care unit of our hospital due to head trauma between January 2019 and May 2021 were retrospectively screened and included in our study. Patient files, archive records and hospital automation recording system were examined comprehensively. GCS, ISS and RTS values of all patients were determined and their effects on prognosis were examined.

Results: The median age of the patients was 24.5 (12.0-39.8) years and 85 (81.7\%) were male. The median GCS was 13 (9.315.0), ISS was 25 (25-41), and RTS was 11 (9-12) on admission. The most common cause of head trauma was falls from height in all age categories except the 19-64 age range. However, the most common cause was explosion or gunshot injury (31.4\%) in this age group. In-hospital mortality was developed in $16(15.4 \%)$ patients. When compared with patients who did not develop in-hospital mortality, patients who developed mortality had significantly higher ISS values $(P<0.001)$, whereas lower RTS $(P<0.001)$ and GCS $(P<0.001)$ values on admission. The AUC value of RTS $(0.968)$ for predicting in-hospital mortality was found to be higher than the AUC values of ISS (0.947) and GCS (0.866).

Conclusions: In our study, the role of the most commonly used risk scores in daily practice for predicting in-hospital mortality was investigated in head trauma patients hospitalized in the intensive care unit. Although all risk scores on admission had a good diagnostic value in predicting high-risk patients with poor in-hospital prognosis, RTS was found to be superior score than other clinical risk scores for predicting mortality.

Keywords: Head trauma, in-hospital mortality, clinical risk scores
Sorumlu Yazar / Corresponding Author

Dr. Tuğba BINGÖL TANRIVERDi

Sağıık Bilimleri Üniversitesi, Mehmet Akif İnan Eğitim ve Araştırma Hastanesi, Anesteziyoloji ve Reanimasyon Bölümü, Şanlıurfa, Türkiye

E-mail: tuggbabingol@gmail.com

Geliş tarihi / Received: 08.09.2021

Kabul tarihi / Accepted: 09.11.2021

DOI: 10.35440/hutfd.992695 


\section{Giriş}

Kafa travmaları tüm dünyada sık görülen, fonksiyonel bozukluklar ve ölümlere neden olabilen ve yoğun bakım takibi gerektirebilen önemli bir sağlık sorunudur $(1,2)$. Ülkemizde ve tüm dünyada şehirleşme ve endüstrileşmenin doğal bir sonucu olarak iş kazaları ve trafik kazaları ile son yüzyılda yaşanan büyük savaşlara ve bireysel silahlanmaya bağlı ateşli silah yaralanmaları kafa travmalarının en sık nedenleridir $(3,4)$. Ülkelere ve hatta bölgelere göre sıklığı değişmekle beraber yıllık kafa travması sıklığı 100.000' de 200-300 olarak bildirilmektedir (5). Yoğun tedavilere rağmen özellikle de ağır kafa travması geçiren hastaların çoğunda ya sekel kalmakta ya da ölüm gözlenmektedir. Dünya sağlık örgütü verilerine göre, her yıl ölüm veya hastane yatışı ile sonlanacak kadar ciddi en az 10 milyon kafa travması olayı meydana gelmekte ve yılda 80.000 kişinin kafa travmasına bağlı olarak sakat kaldığı bildirilmektedir (6). Bu nedenle, kafa travması ile başvuran hastalarda ilk müdahale çok hızlı bir şekilde yapılmalı ve kötü prognoza sahip olabilecek yüksek riskli hastalar belirlenmelidir. Kafa travması sonrası prognozu etkileyen en önemli faktörler hastaya acil serviste etkili bir şekilde müdahale edilmesi, cerrahi müdahale gereken hastaların hızlı bir şekilde operasyona alınması ve yoğun bakım ünitesindeki izlem sürecidir. Bu hastaların tanı ve tedavisindeki esas amaç, sekonder beyin hasarına neden olabilecek olayları en aza indirgemektir $(7,8)$. Illk başvuruda kötü prognoza sahip yüksek riskli hastaları belirleyebilmek, bu hastalara uygulanacak multidispliner yaklaşımlar ile sekel ve ölüm oranları azaltmak açısından önemlidir. Bu amaçla birçok parametre, özellikle de bazı klinik skorlama sistemleri, kullanılabilir. Glaskow koma skalası (GKS), yaralanma şiddet skoru (injury severity score, ISS) ve revize travma skoru (RTS) kafa travmalı hastaların ilk değerlendirmesinde olumsuz sonuçları tahmin etmede ve klinik karar vermede en çok kullanılan puanlama sistemleridir $(9,10)$.

Yapılan epidemiyolojik çalışmalarda, ülkemizde çocuk ve genç erişkinlerde kafa travmasının daha sık olduğu ve erkeklerin kadınlara göre daha fazla kafa travmasına maruz kaldıkları gösterilmiştir $(1,3,5)$. Ancak, ülkemizde tüm verilerin toplandığı bir havuz ve merkezi kayıt sisteminin henüz tam olarak sağlıklı çalışmamasından dolayı kafa travmasının insidansı ve epidemiyolojisi ile ilgili bilgiler yetersizdir. Ek olarak, kullanılan klinik risk skorlarının hastane içi ölüm ilişkisini inceleyen çalışmalarda oldukça kısıtlıdır. Çalışmamızın amacı kafa travması nedeniyle hastanemize başvuran ve yoğun bakımda takip edilen hastaların klinik özelliklerini sunmak, yaş kategorilerine göre altta yatan etiyolojik faktörleri belirlemek ve kullanılan klinik risk skorlarının hastane içi ölüme etkisini saptamaktır.

\section{Materyal ve Metod}

Bu çalışma, Harran Üniversitesi Klinik Araştırmalar Etik Kurulu onayı alındıktan sonra (tarih: 07.06.2021, no: HRU/21.11.18), Sağlık Bilimleri Üniversitesi Mehmet Akif İnan Eğitim ve Araştırma Hastanesi'nde yapılmıştır. Ocak 2019 - Mayıs 2021 tarihleri arasında hastanemiz acil servisine tekli veya çoklu travma nedeniyle başvuran hastalar içerisinde kafa travması mevcut olan ve bilgisayarlı beyin tomografisi çekilen hastalar geriye dönük olarak tarandı. Hastaların verileri için hasta dosyaları, arşiv kayıtları ve hastane otomasyon kayıt sistemi ayrıntılı olarak incelendi. Verilerine ulaşılamayan hastalar çaıışma dışı bırakıldı. Sonuç olarak, belirtilen tarihlerde kafa travması nedeniyle yoğun bakım ünitemize yatırılarak tedavi edilmiş olan 104 hasta çalışmaya dahil edilerek kayıtları retrospektif olarak değerlendirildi.

Tüm hastaların temel demografik verileri, eşlik eden hastalıkları, travma etiyolojisi, eşlik eden travma mevcudiyeti, ilk başvurudaki Glaskow Koma Skalası (GKS), revize edilmiş travma skoru (RTS) ve yaralanma şiddeti skoru (ISS) değerleri, cerrahi müdahale gereksinimleri, yoğun bakım ünitesinde kalış süreleri ve bu süredeki gereksinimleri, ilk başvuru anındaki laboratuvar ve bilgisayarlı beyin tomografisi verileri ile hastane içi sonlanımları kaydedildi. Böylece hastaların demografik, klinik, laboratuvar ve radyolojik bulguları elde edilerek değerlendirmeler yapıldı. Tüm hastaların GKS, ISS ve RTS' leri hesaplanırken güncel literatürde belirtilen sistem değerlendirmeleri yapılarak buna göre puanlandırmalar yapıldı $(9,10)$. Ek olarak hastalar yaş gruplarına göre kategorize edilerek (0-2 yaş: bebeklik dönemi, 3-5 yaş: oyun çocuğu dönemi, 6-18 yaş: okul çocuğu dönemi, 19-64 yaş: erişkin dönemi, $\geq 65$ yaş: ileri yaş dönemi) altta yatan etiyolojik sebep ayrıntılı olarak incelendi.

\section{İstatistiksel analiz}

Çalışmadaki verilerin analizi için SPSS 20.0 programı kullanıldı. İncelenen değişkenlerin normal dağılıma uyup uymadıkları KolmogorovS mirnov testi ile değerlendirildi. Normal dağılıma uyan sürekli değişkenler ortalama \pm standart sapma şeklinde gösterildi ve bağımsız örneklem $t$ testi ile karşılaştırıldı. Normal dağılıma uymayan sürekli değişkenler ortanca (25.-75. çeyreklikler) şeklinde gösterildi ve Mann-Whitney U testi ile karşılaştırıldı. Kategorik veriler sayı ve yüzde olarak gösterildi ve ki-kare testi ile karşılaştırıldı. Korelasyon analizleri için Spearman korelasyon katsayısı kullanıldı. Başvurudaki skorların hastane içi ölümü öngördürmede eğri altında kalan alanlarını (AUC değerlerini) belirlemek için ROC (Receiver Operating Characteristic) curve analizi kullanıldı. P değerinin 0,05'ten küçük olması istatistiksel anlamlılık olarak kabul edildi.

\section{Bulgular}

Çalışmamıza hastanemiz yoğun bakımında kafa travması nedeniyle yatırılmış 104 hasta dahil edildi. Hastaların yaş ortancası 24.5 (12.0-39.8) yıl idi. Yaş kategorilerine bakıldığında hastaların \%3,8'i (4 hasta) 0-2 yaş aralığında, \%6,7'si (7 hasta) 3-5 yaş aralığında, \%26,9'u (28 hasta) 6-18 yaş aralığında, \%49'u (51 hasta) 19-64 yaş aralığında ve \%13,5'i (14 hasta) 65 yaş ve üzerinde idi. Başvurudaki skorlara bakıldığında; GKS ortancası 13 (9.3-15.0), ISS ortancası 25 (25-41), RTS ortancası ise 11 (9-12) olarak tespit edildi. Kafa travmanın en sık nedeni $\% 45,2$ ile yüksekten düşme idi(Tablo 1 ). 
Tablo 1. Kafa travması ile yatırılan hastaların demografik özellikleri, hastaneye başvuru sebepleri ve eşlik eden travmalar

\begin{tabular}{|c|c|c|}
\hline Değişkenler & Olgu $(n=104)$ & $\%$ \\
\hline \multicolumn{3}{|l|}{ Cinsiyet } \\
\hline Erkek & 85 & 81.7 \\
\hline Kadın & 19 & 18.3 \\
\hline Ek hastalık (\%) & 11 & 10.6 \\
\hline Hipertansiyon & 8 & 7.7 \\
\hline Geçirilmiş serebrovasküler olay & 3 & 2.9 \\
\hline Koroner arter hastalığı & 2 & 1.9 \\
\hline \multicolumn{3}{|l|}{ Hastaneye başvuru sebepleri } \\
\hline Yüksekten düşme & 47 & 45.2 \\
\hline Araç dışı trafik kazası & 3 & 2.9 \\
\hline Araç içi trafik kazası & 15 & 14.4 \\
\hline Motosiklet kazası & 8 & 7.7 \\
\hline Darp & 14 & 13.5 \\
\hline Patlama veya ateşli silah yaralanması & 17 & 16.4 \\
\hline \multicolumn{3}{|l|}{ Eșlik eden travmaların dağılımı } \\
\hline Maksillofasiyel travma & 22 & 21.2 \\
\hline Göğüs ve/veya akciğer travması & 14 & 13.5 \\
\hline Batın travması & 4 & 3.8 \\
\hline Ortopedik travma & 11 & 10.6 \\
\hline
\end{tabular}

Tablo 2. Yaş kategorilerine göre travma nedenlerinin dağııımı

\begin{tabular}{|c|c|c|c|c|c|}
\hline & $\begin{array}{l}0-2 \text { yaş } \\
n=4,(\%)\end{array}$ & $\begin{array}{l}\text { 3-5 yaş } \\
n=7,(\%)\end{array}$ & $\begin{array}{l}\text { 6-18 yaş } \\
n=28,(\%)\end{array}$ & $\begin{array}{l}\text { 19-64 yaş } \\
n=51,(\%)\end{array}$ & $\begin{array}{l}\geq 65 \text { yaş } \\
n=14,(\%)\end{array}$ \\
\hline Yüksekten düşme & $3(75)$ & $5(71.4)$ & $16(57.1)$ & $13(25.5)$ & $10(71.4)$ \\
\hline Trafik kazaları & $1(25)$ & $2(28.6)$ & $6(21.4)$ & $14(27.4)$ & $3(21.3)$ \\
\hline Araç dışı trafik kazası & 1 & 0 & 1 & 0 & 1 \\
\hline Araç içi trafik kazası & 0 & 1 & 3 & 10 & 1 \\
\hline Motosiklet kazası & 0 & 1 & 2 & 4 & 1 \\
\hline Darp & $0(0)$ & $0(0)$ & $5(17.9)$ & $8(15.7)$ & $1(7.1)$ \\
\hline Patlama veya ateşli silah yaralanması & $0(0)$ & $0(0)$ & $1(3.6)$ & $16(31.4)$ & $0(0)$ \\
\hline
\end{tabular}

Tablo 3. Kafa travması ile yatırılan hastalardaki beyin tomografisi bulguları

\begin{tabular}{lll}
\hline Değişkenler & Olgu & $\%$ \\
\hline Epidural kanama & 64 & 61.5 \\
Subdural kanama & 35 & 33.7 \\
Subaraknoid kanama & 24 & 23.1 \\
İntraserebral kanama & 12 & 11.5 \\
Lineer fraktür & 13 & 12.5 \\
Çökme fraktürü & 21 & 20.2 \\
Pnömosefali & 5 & 4.8 \\
Kafa kaidesi kıı̆ı̆ı & 1 & 1.0 \\
\hline
\end{tabular}

Yaş kategorilerine göre travma nedenlerinin dağılımı Tablo 2'de gösterilmektedir. Yapılan değerlendirmede 19-64 yaş aralığı dışındaki diğer tüm yaş kategorilerinde kafa travmasının en sık nedeninin yüksekten düşme olduğu görüldü. 1964 yaş aralığında ise kafa travmasının 1. en sık nedeni patlama veya ateşli silah yaralanması $(\% 31,4)$ iken, 2 . en sık nedeni ise trafik kazaları $(\% 27,4)$ idi.

Hastaların başvuru sırasındaki beyin tomografi bulguları Tablo 3'te gösterilmektedir. Beyin tomografisi bulgularına bakıldığında; epidural hematom(\%61,5), subdural hematom $(\% 33,7)$ ve subaraknoid kanamanın $(\% 23,1)$ en sık görülen patolojiler olduğu tespit edildi. Hastaların hastaneye yatışı sırasında alınan kan örnekleri Tablo 4'te sunulmaktadır. Beyaz küre sayısı dışında diğer temel biyokimyasal, kan gazı ve hemogram parametrelerinin ortalama ve/veya ortanca değerlerinin referans aralıklar arasında olduğu saptandı. 
Tablo 4. Kafa travması ile yatırılan hastaların hastaneye başvurularındaki laboratuvar değerleri

\begin{tabular}{lll}
\hline Değişkenler & Sonuç & Referans aralık \\
\hline Üre, $\mathrm{mg} / \mathrm{dl}$ & $28.5(22.0-26.0)$ & $10-50$ \\
Kreatinin, $\mathrm{mg} / \mathrm{dl}$ & $0.7 \pm 0.3$ & $0.7-1.2$ \\
Sodyum, $\mathrm{mEq} / \mathrm{L}$ & $138.8 \pm 2.9$ & $136-145$ \\
Potasyum, $\mathrm{mEq} / \mathrm{L}$ & $4.2 \pm 0.5$ & $3.5-5.1$ \\
$\mathrm{CRP}, \mathrm{mg} / \mathrm{L}$ & $1.0(0.5-3.3)$ & $0-5$ \\
Albümin, g/dl & $4.1 \pm 0.6$ & $3.5-5.2$ \\
$\mathrm{pH}$ & $7.4 \pm 0.1$ & $7.31-7.41$ \\
Laktat, $\mathrm{mmol} / \mathrm{L}$ & $1.8(1.2-2.8)$ & $0.5-2.2$ \\
Beyaz küre, $\mathrm{x} 10^{3} / \mathrm{ml}$ & $14.0(9.9-18.3)$ & $3.7-10.1$ \\
Hematokrit, \% & $39.5 \pm 5.7$ & $37.7-53.7$ \\
Trombosit, $\mathrm{x} 10^{3} / \mathrm{ml}$ & $266.8 \pm 84.1$ & $155-400$ \\
\hline
\end{tabular}

Tablo 5. Kafa travması ile yatırılan hastaların hastanede kalış süreleri, hastanedeki gereksinimleri ve sonlanımları

\begin{tabular}{lll}
\hline Değişkenler & Olgu $(\mathbf{n}=\mathbf{1 0 4})$ & $\%$ \\
\hline Operasyon gereksinimi & 42 & 40.4 \\
\hline Mekanik ventilatör gereksinimi & 34 & 32.7 \\
\hline İnotrop gereksinimi & 19 & 18.3 \\
\hline Hemodiyaliz gereksinimi & 2 & 1.9 \\
\hline Kan ürünleri gereksinimi & & \\
Eritrosit süspansiyonu & 38 & 36.5 \\
Taze donmuş plazma & 29 & 27.9 \\
Trombosit süspansiyonu & 4 & 3.8 \\
\hline Trakeostomi & 4 & 3.8 \\
\hline Beyin ölümü & 3 & 2.9 \\
\hline Bakım hastası & 4 & 3.8 \\
\hline Sonuç & & \\
\hline Taburcu & 84 & 80.8 \\
Ölüm & 16 & 15.4 \\
Sevk & 1 & 1 \\
\hline Tedaviyi reddetme & 3 & 2.9 \\
\hline
\end{tabular}

Beyaz küre sayısı ise referans aralıklarından daha fazla olarak tespit edildi. Korelasyon analizinde; lökosit sayıSI ISS $(r=0.361, p<0.001)$ ile pozitif bir şekilde korele iken, GKS ( $r=$ $-0.437, p<0.001)$ ve RTS $(r=-0.398, p<0.001)$ ile negatif bir şekilde korele idi.

Hastaların hastanede kalış süreleri, hastanedeki gereksinimleri ve sonlanımları Tablo 5'te gösterilmektedir. Hastaların yoğun bakımda kalış süresi ortalama 3 (1-5) gün idi ve 34 $(\% 32,7)$ hastada mekanik ventilatör gereksinimi oluştu. 19 (18.3) hastada yoğun bakım takibi sırasında inotrop gereksinimi, $2(\% 1,9)$ hastada ise geçici hemodiyaliz gereksinimi meydana geldi. Hastane içi ölüm $16(\% 15,4)$ hastada görüldü.

Ölümlerin sebepleri incelendiğinde; $7(\% 43,75)$ hastada patlama veya ateşli silah yaralanmasına bağlı, 5 (\%31,25) hastada yüksekten düşmeye bağlı, $3(\% 18,75)$ hastada araç içi trafik kazasına bağlı, $1(\% 6,25)$ hastada ise dışı trafik kazasına bağlı ölüm meydana geldiği görüldü.
Beyin tomografisi sonuçlarına bakıldığında; ölen hastalarda subdural kanama (11 [\%68.8]), subaraknoid kanama (8 [\%50]) ve epidural kanama (4 [\%25]) sıklıklarının oldukça yüksek olduğu, ancak lineer fraktür (1 [\%6.3]), çökme fraktürü (1 [\%6.3]) ve pnömosefali (0 [\%0]) sıklıklarının oldukça nadir olduğu tespit edildi. Ölüm gözlenen hastaların $\% 43,75^{\prime}$ inde ek bir travma mevcut idi. Ek olarak, ölen hastaların 12'si (\%75) 19-64 yaş aralığında iken, 4'ü ise (\%25) 65 yaş ve üstündeki hastalar idi.

Çalışmamızda ayrıca, başvurudaki skorların hastane içi ölüm ile ilişkisi de incelendi. Hastane içi ölüm gelişmeyen hastalar ile karşılaştırıldığında; hastane içi ölüm gelişen hastaların başvuru sırasındaki ISS değerleri anlamlı olarak daha yüksek iken (Şekil 1A), RTS (Şekil 1B) ve GKS (Şekil 1C) değerleri anlamlı olarak daha düşük idi. Bu 3 skorun hastane içi ölümü öngördürmedeki AUC değerleri ROC curve analizi ile belirlendi. RTS'nin hastane içi ölümü öngördürmedeki AUC değeri (0.968), ISS (0.947) ve GKS'nin (0.866) AUC değerlerinden daha yüksek olarak tespit edildi (Şekil 2). 

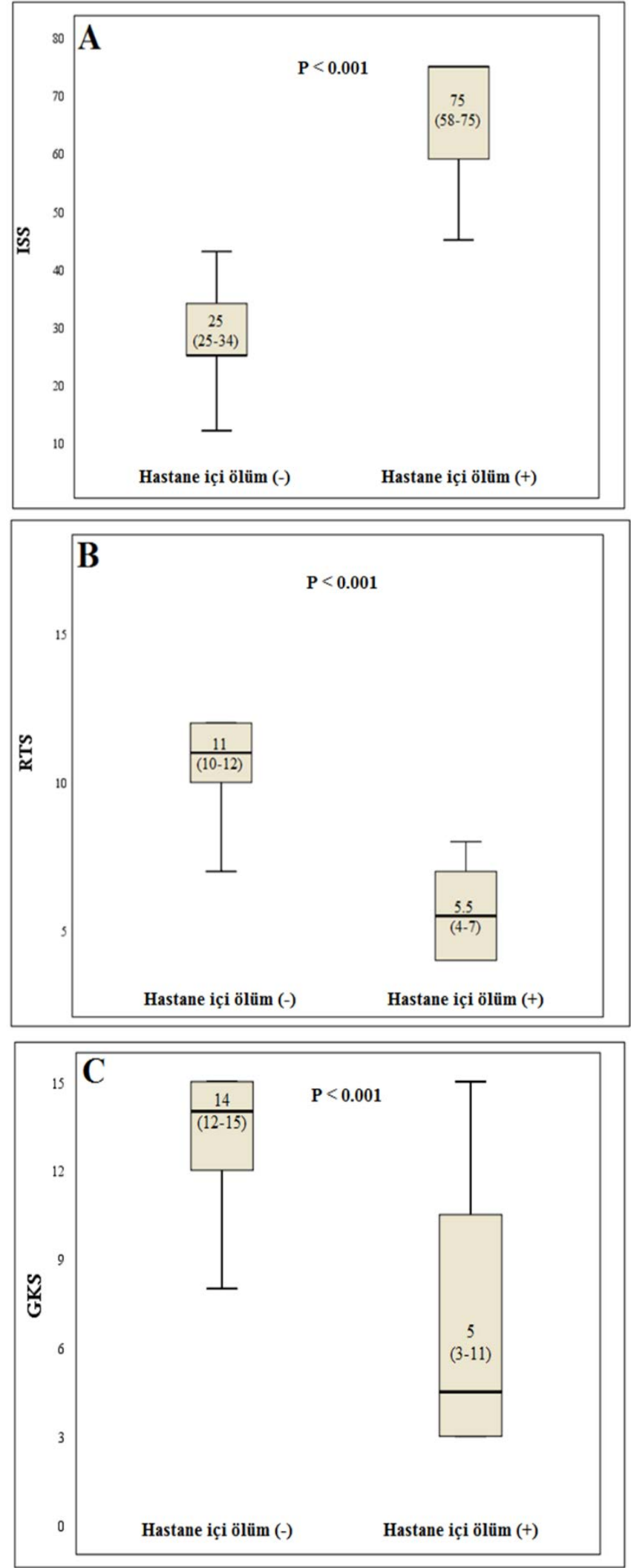

Şekil 1. Hastane içi ölüm gözlenen ve gözlenmeyen grupların yaralanma şiddet skorlarının (A), revize travma skorlarının (B) ve Glaskow Koma Skalalarının (C) karşılaştırılması

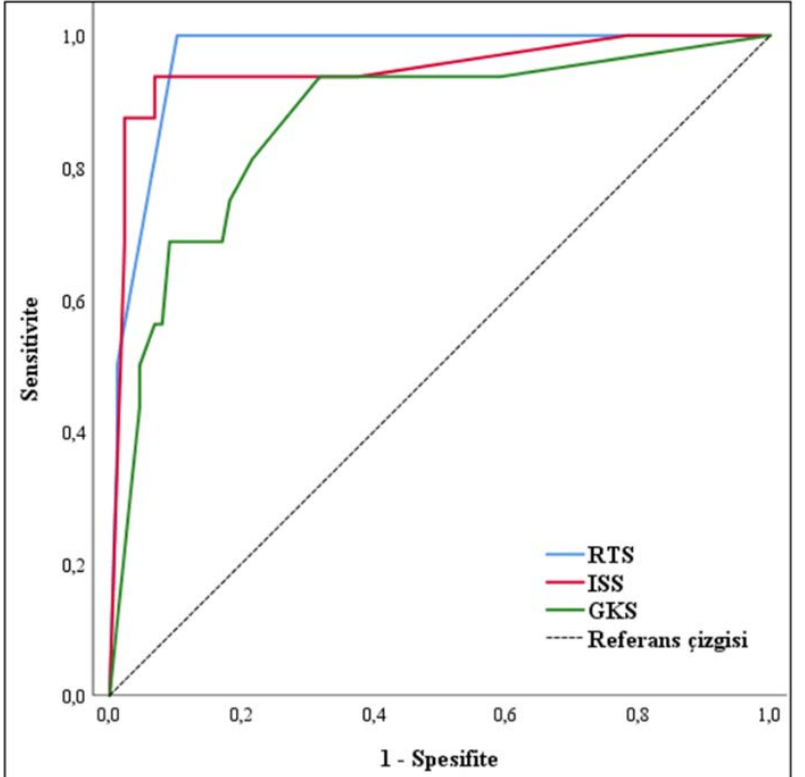

Şekil 2. Yaralanma şiddet skoru, revize travma skoru ve glaskow koma skalasının hastane içi ölümü öngördürmedeki ROC curve analizi

\section{Tartışma}

Bu çalışmamızda, yoğun bakım ünitemize yatırılarak takip ve tedavi edilmiş olan 104 kafa travmalı hastanın klinik özelliklerini geriye dönük olarak inceledik. Çalışmamızın ana bulguları şu şekilde özetlenebilir: (I) kafa travmalı hastaların büyük bir çoğunluğu $(\% 81,7)$ erkek cinsiyette ve en sık olarak 19-64 yaş aralığında (\%49) idi, (II) 19-64 yaş aralığı dışındaki diğer tüm yaş kategorilerinde kafa travmasının en sık nedeni yüksekten düşme iken, bu yaş aralığında en sık neden patlama veya ateşli silah yaralanması idi, (III) hastane içi ölüm gözlenen hastaların büyük çoğunluğu 19-64 yaş aralığında (\%75) idi ve en sık etiyolojik neden patlama veya ateşli silah yaralanması $(\% 43,75)$ idi, (IV) başvuru zamanındaki revize travma skoru, hastane içi mortaliteyi öngörmede diğer skorlara göre (ISS ve GKS) daha yüksek bir duyarlılığa sahipti. Kafa travmaları; şehirleşme, endüstrileşme ve son yıllarda yaşanan savaşlar ile bireysel silahlanmaya bağlı olarak tüm dünyada görülme sıklığı giderek artan ciddi bir durumdur (14,11 ). Yapılan çalışmalarda kafa travmalarına bağlı ölümün tüm travmalara bağlı ölümlere oranının $1 / 3$ olduğu belirtilmektedir $(11,12)$. Meydana getirdiği sakatlıklar, iş gücü kaybı ve sağlık giderleri de düşünüldüğü zaman kafa travmaları önemli bir sağıık sorunu olarak karşımıza çıkmaktadır. Eğitim ve alınacak önlemler ile sıklığı azaltılabilecek olan kafa travmaları hakkında literatürde birçok çalışma bulunmaktadır. Ancak, ülkemizde konu ile ilgili detaylı çalışmalar nispeten yetersizdir. Biz de ülkemizin veri tabanına katkıda bulunmak amacıyla, bu çalışmamızda yoğun bakımda yatarak tedavi gören kafa travmalı hastaların klinik özelliklerini, yaş kategorilerine göre altta yatan etiyolojik nedenleri ve başvurudaki skorların hastane içi ölüme etkisini inceledik. 
Yapılan çalışmalarda özellikle genç erişkinlerin kafa travmalarına daha sık maruz kaldıkları ve erkeklerde kafa travması sıklığının kadınlara oranla daha fazla olduğu gösterilmiştir (12-15). Bizim çalışmamızda da yoğun bakımda yatarak tedavi gören kafa travmalı hastaların büyük bir çoğunluğunun erkek cinsiyette olduğu ve erkeklerde kadınlara oranla 4,5 kat daha sık kafa travması meydana geldiğini tespit ettik. Ek olarak, çalışmamızda kafa travmalarının yaklaşık yarısının 19-64 yaş aralığında olduğunu saptadık. Dolayısıyla çalışmamızda elde edilen verilerin mevcut literatür bilgileri ile örtüştüğü söylenebilir. Özellikle bu yaş gurubundaki erkeklerde daha sık kafa travması görülmesinin nedeni, bu kişilerin günlük hayatta sosyokültürel olarak daha fazla aktif olmalarına ve çalışma açısından daha etkin bir rol oynamalarına bağlanabilir. Bu nedenle, özellikle de bu yaş gurubundaki kişilere yönelik eğitimler yapılması koruyucu hekimlik açısından önem arz edebilir.

Kafa travmasının sıklığı ve kafa travmasının etiyolojisinde rol oynayan faktörler ülkelere ve hatta bölgelere göre bile değişkenlik göstermektedir (5). Çalışmamızda yoğun bakımda yatarak tedavi gören kafa travmalı hastaların etiyolojilerinde en sık nedenin yüksekten düşme $(\% 45,2)$ olduğu tespit edildi. Çalışmamıza benzer şekilde daha önce yapılan çalışmalarda da kafa travmalarında en sık nedenin yüksekten düşme olduğu belirtilmektedir (3, 11-13). Yüksekten düşmenin bu denli sık olmasının nedeni bölgenin sosyokültürel özelliğinden kaynaklanabilir. Yaz aylarında havanın aşırı sıcak olması nedeniyle damda yatmaların sık olması ve olguların çoğunluğundan damdan düşmelerin önemli bir etiyolojik neden olduğu söylenebilir. Çalışmamızda ek olarak yaş kategorilerine göre etiyolojik nedenlerine bakıldı ve 19-64 yaş aralığı dışındaki diğer tüm yaş kategorilerinde kafa travmasının en sık nedeninin yüksekten düşme olduğu tespit edildi. Daha önceki çalışmalarda bu yaş aralığında özellikle de trafik kazalarının en önemli neden olduğu rapor edilmiş olsa da $(3,4,11)$, çalışmamızda diğer çalışmalardan farklı olarak bu yaş gurubunda kafa travmasının en sık nedeninin patlama veya ateşli silah yaralanması $(\% 31,4)$ olduğu, trafik kazalarının ise bu yaş kategorisinde 2. en sık etiyolojik neden olduğu görüldü. Bunun nedeni bölgenin sosyokültürel özelliklerinden ve jeopolitik konumundan kaynaklanabilir. Bölgede, bireysel silahlanmanın fazla olması ve bölgeye komşu ülkelerde devam eden savaşlara bağlı olarak bu yaş grubunda ateşli silah yaralanmaları daha sık meydana gelmiş olabilir. Çalışmamızda yoğun bakım takibindeki sonlanımlara baktığımızda, hastaların \%15,4'ünde (16 hasta) hastane içi ölüm gözlendi. Çalışmamızdaki ölüm oranları ülkemizde yapılan diğer çalışmalardaki ölüm oranları ile benzerlik göstermektedir $(4,12)$. Ölüm gelişen hastalar incelendiğinde, ölümün en sık nedenin patlama veya ateşli silah yaralanmasına $(\% 43,75)$ bağlı olduğu tespit edildi. Ek olarak, ölüm gözlenen hastaların \%43,75'inde ek bir travma mevcut idi. Çalışmamıza benzer şekilde daha önceki çalışmalarda da ateşli silah yaralanmalarına bağlı kafa travmalarında ölümün daha sık olduğu ve diğer sistem travmalarının eşlik ettiği hastaların daha kötü prognoza sahip olduğu gösterilmiştir $(2,14,16)$.
Bulgularımız mevcut literatür verilerini desteklemektedir. Kafa travması ile başvuran hastalarda ilk başvuru anında hangi hastaların daha riskli olduğunu belirlemek hayati öneme haizdir. Daha yüksek riske sahip olan hastaları önceden tespit edebilmek, bu hastalara multidisipliner yaklaşımlar ve daha yoğun bir takip-tedavi süreci ile prognoz iyileştirilebilir $(17,18)$. Bu amaçla günlük pratikte en sık kullanılan skorlama sitemleri GKS, ISS ve RTS'dir. Yapılan çalışmalarda, başvuru sırasında düşük GKS ve RTS skorunun ve yüksek ISS skorunun kötü prognoz ile ilişkili olduğu tespit edilmiştir $(9,19-21)$. Çalışmamızda da hastane içi ölüm gözlenen hastalarda GKS ve ISS skorlarının anlamlı olarak daha düşük olduğu ve ISS skorunun ise daha yüksek olduğu tespit edildi. $\mathrm{Bu}$ bulgular, kafa travması ile başvuran olgularda başvuru anındaki GKS, ISS ve RTS'nin yüksek riskli hastaları saptamada ve prognozu belirlemede kullanılabilecek önemli birer risk skorları olduklarını göstermektedir. Ancak bu risk skorlarından hangisinin ölümü daha iyi öngördüğü henüz tam olarak aydınlatılamamıştır (19). Yousefzadeh-Chabok ve ark.'ları çalışmalarında ISS, RTS ve travma skoru-yaralanma şiddet skorunun (TRISS) skorlarını karşılaştırmış ve TRISS'ın hastane içi ölümü öngörmede diğer skorlara göre daha üstün olduğunu belirtmişlerdir (9). Ancak bu çalışmada sadece yaşlı hastalar incelendiği için elde edilen bulguları tüm travma hastalarına genelleyemeyiz. Bizim çalışmamızda ise tüm yaş gurubundaki hastalar incelenmiş ve bu 3 klinik skorun hastane içi ölümü öngörmedeki performanslarını belirlemek için ROC curve analizi yapılmıştır. Yapılan analizde RTS için eğri altında kalan alan (0.968), ISS (0.947) ve GKS (0.866) için eğri altında kalan alandan daha fazla idi. Bulgular, kafa travması ile yoğun bakımda izlenen hastalarda başvurudaki RTS'nin diğer skorlara göre yüksek riskli hastaları öngörmede daha iyi bir tanısal değere sahip olduğunu göstermektedir. Ancak, konu hakkında daha iyi bilgi sahibi olmak için ileriye dönük ve çok sayıda hastanın incelendiği çaIışmalara ihtiyaç olduğunu düşünmekteyiz.

Yapılan çalışmalarda, travmadan sonra ölçülen kan lökosit düzeyinin travmanın şiddetine bağlı olarak arttığı gösterilmiştir. Ek olarak, artmış lökosit sayısının risk skorları ile ilişkili olduğu ve prognozu tahmin etmede faydalı oldukları da gösterilmiştir $(22,23)$. Literatürdeki çalışmalara benzer şekilde, biz de çalışmamızda lökosit sayısının ISS ile pozitif bir şekilde korele olduğunu, ancak GKS ve RTS ile negatif bir şekilde korele olduğunu tespit ettik. Tüm bu bulgular beraber değerlendirildiğinde, kafa travması ile başvuran hastalarda artmış lökosit sayısının, daha riskli hastaları öngörebileceği söylenebilir.

Çalışmamızın en büyük kısıtıılığı hasta sayısının nispeten yetersiz olmasıdır. İkinci olarak, yoğun bakımda yatarak takip ve tedavi edilen kafa travmalı hastaları incelediğimiz için elde ettiğimiz bulgular tüm kafa travmalı hastalara genellenemez. Üçüncü olarak, çalışmamızda TRISS değeri değerlendirilmemiştir. Bunun hesaplanması ve ölüm üzerindeki etkisinin incelenmesi çalışmamıza ek katkı sağlayabilirdi. Son olarak, taburculuk sonrası hastaları uzun dönem takip ede- 
medik. Hastaların uzun dönem takiplerinin ve prognoz değerlendirmelerinin yapılması çalışmamızın değerini arttırabilirdi.

Sonuç olarak, kafa travmaları, tüm dünyada sık görülen ve yoğun tedavilere rağmen sekel ya da ölüm oranları yüksek olan önemli bir sağlık sorunudur. Çalışmamızda, hastane içi ölümün daha çok ateşli silah yaralanmalarına bağıı kafa travmalarında ve diğer sistem travmalarının eşlik ettiği hastalarda olduğu görüldü. Her ne kadar başvurudaki risk skorları hastane içi prognozu kötü olabilecek yüksek riskli hastaları öngörmede iyi bir tanısal değere sahip olsa da RTS'nin diğer klinik risk skorlarına göre ölümü öngörmede daha üstün bir skor olduğu tespit edildi.

Etik onam: Çalışma için Harran Üniversitesi Klinik Araştırmalar Etik Kurulundan, etik onay alındı (Tarih: 07.06.2021, no: HRU/21.11.18)

\section{Yazar Katkıları:}

Konsept: T.B.T., T.E.

Literatür Tarama: T.B.T., T.E.

Tasarım: T.B.T., T.E.

Veri toplama: T.B.T., T.E.

Analiz ve yorum: T.B.T., T.E.

Makale yazımı: T.B.T., T.E.

Eleştirel incelenmesi: T.B.T., T.E.

Çıkar Çatışması: Herhangi bir çıkar çatışmamız bulunmamaktadır. Finansal Destek: Araştırma kapsamında herhangi bir kurum ya da kuruluştan finansal destek sağlanmamıştır.

\section{Kaynaklar}

1. Dewan MC, Rattani A, Gupta S, Baticulon RE, Hung YC, Punchak $M$, et al. Estimating the global incidence of traumatic brain injury. J Neurosurg. 2018:1-18.

2. Rutland-Brown $W$, Langlois JA, Thomas KE, Xi YL. Incidence of traumatic brain injury in the United States, 2003. J Head Trauma Rehabil. 2006;21(6):544-8.

3. Çökük A, Kozacı N, Ay Mo, Açıkalın A, Seviner M, Satar S. Acil Servise Başvuran Kafa Travması Olgularının Değerlendirilmesi. Cukurova Medical Journal. 2013;38(1):63-71.

4. Işık HS, Bostancı U, Yıldız Ö, Özdemir C, Gökyar A. Kafa travması nedeniyle tedavi edilen 954 erişkin olgunun retrospektif değerlendirilmesi: Epidemiyolojik çalışma. Ulus Travma Acil Cerrahi Derg. 2011;17(1):46-50.

5. Sencer A, İmer M. Günümüzde Kafa Travmasına Genel Bir Bakış. Turkiye Klinikleri J Surgery. 2004;9(3):188-95.

6. Murray CJ, Lopez AD. Global Health Statistics. Geneva: World Health Organization; 1996.

7. Deniz T, Yılmaz B. Acil Serviste Kafa Travmalı Hastaya Yaklaşım. Turkiye Klinikleri J EmergMed-Special Topics. 2017;3(1):26-34.

8. Demirdöven BT, Güvenç E, Küçük $M$, Uyar ME. Acil Servise Başvuran Kafa Travmalı Hastaların Bilgisayarlı Tomografi ile Değerlendirilmesi. Forbes J Med. 2020;1(1):1-4.

9. 9-Yousefzadeh-Chabok S, Hosseinpour M, KouchakinejadEramsadati L, Ranjbar F, Malekpouri R, Razzaghi A, et al. Comparison of Revised Trauma Score, Injury Severity Score and Trauma and Injury Severity Score for mortality prediction in elderly trauma patients. Ulus Travma Acil Cerrahi Derg. 2016;22(6):536-40.

10. Cook NF. The Glasgow Coma Scale: A European and Global
Perspective on Enhancing Practice. Crit Care Nurs Clin North Am. 2021;33(1):89-99.

11. Akgül $M$, Burulday V. Acil Ünitesine Kafa Travması Nedeni ile Başvuran Olguların Değerlendirme Sonuçları. Kırıkkale Üniversitesi Tıp Fakültesi Dergisi. 2016;18(3):134-8.

12. Karasu A, Sabanci PA, Cansever T,Hepgül KT, Imer M, Dolaş I, et al. Epidemiological Study in Head Injury Patients. Ulus Travma ve Acil Derg. 2009;15:159-63.

13. Işık H, Gökyar A, Yıldız Ö, Bostancı U, Özdemir C. Pediatric head injuries, retrospective analysis of 851 patients: an epidemiological study. Ulus Travma Acil Cerrahi Derg. 2011;17:166-72.

14. Langlois JA, Rutland-Brown W, Wald MM. The epidemiology and impact of traumatic brain injury: a brief overview. J Head Trauma Rehabil.2006;21:375-8.

15. Ökten Ai, Ergün R, Akdemir G, Okay Ö, Duyar M, Anasız H ve ark. Kafa Travmalarının Epidemiyolojisi: 1450 Olgunun Verileri. Ulus Travma Derg. 1997;3(4):291-7.

16. Luerssen TG, Klauber MR, Marshall LF. Outcome from head injury related to patient's age. A longitudinal prospective study of adult and pediatric head injury. J. Neurosurgery. 1988;3:409-16.

17. Guzzo JL, Bochicchio GV, Napolitano LM, Malone DL, Meyer W, Scalea TM. Prediction of outcomes in trauma: anatomic or physiologic parameters? J Am Coll Surg. 2005;201:8917.

18. MacKenzie EJ, Rivara FP, Jurkovich GJ, Nathens AB, Frey KP, Egleston $\mathrm{BL}$, et al. A national evaluation of the effect of trauma-center care on mortality. N Engl J Med. 2006;354:36678.

19. Chawda MN, Hildebrand F, Pape HC, Giannoudis PV. Predicting outcome after multiple trauma: which scoring system? Injury 2004;35:347-58.

20. Selvi F, Karadaş S, Gönüllü H. Kafa Travmalı Hastalarda Epidemiyolojik Veriler ve Bölgesel Faktörler. Sakarya Tıp Dergisi. 2017;7(1):1-1.

21. Hukkelhoven CW, Steyeberg EW, Rampon AJ, Farace E, Habbema JDF, Marshall LF, et al. Patient age and outcome following severe traumatic brain injury: an analysis of 5600 patients. J Neurosurg 2003; 99:666-73.

22. Akköse $S$, Bulut $M$, Armağan $E$, Balci $V$, Yolgösteren $A$, Ozgüç $\mathrm{H}$. "Does the leukocyte count correlate with the severity of injury?." Ulus Travma Derg. 2003;9(2):111-113.

23. 23-Gürkanlar $D$, Lakadamyali $H$, Ergun $T$, Yilmaz $C$, Yücel $E$, Altinörs N. Predictive value of leucocytosis in headtrauma. Turkish Neurosurgery. 2009;19(3):211-215. 